заболеваемости и стоматологическим проблемам.

Дальнейшие

исследования

взаимосвязи между изучаемыми факторами и развитием мочекаменной болезни среди населения Амурской области будут проводиться с учетом комплексной оценки химического состава питьевой воды населенных пунктов.

\section{Литература}

1. Lin W.Y., Lai M.M., Li C.I. et al. In addition to insulin resistance and obesity, brachial-ankle pulse wave velocity is strongly associated with metabolic syndrome in Chinese-a populationbased study (Taichung Community Health Study, TCHS) // J Atheroscler Thromb. 2009. Vol.16. P. 105-112.

2. Материалыдля государственногодоклада « состоянии санитарно-эпидемиологического благополучия населения в Российской Федерации в 2018 году» по Амурской области.

3. Коршунова Н.В. Сравнительная токсикологогигиеническая оценка биологической активности основных компонентов отходов ЦПБ и продуктов их трансформации применительно к проблеме санитарной оценки водоемов: дис. канд. мед. наук.: 14.00.07. Ленинград, 1987. 224 с.

4. Сорокина А.Л., Попов А.А., Курганова О.П. Медико-социальные аспекты природопользования. Качество питьевых вод (на примере южных районов Амурской области)// Бюллетень физиологии и патологии дыхания. 2013. № 47. С. 15-19.

Статья поступила в редакцию 20.09.2019

\section{Координаты для связи}

Коршунова Наталья Владимировна, д.м.н., профессор, заведующая кафедрой общей гигиены ФГБОУ ВО Амурская ГМА Минздрава России. E-mail: korshunova1957@yandex.ru

Гнитюк Ольга Андреевна, аспирант кафедры общей гигиены ФГБОУ ВО Амурская ГМА Минздрава России. E-mail: oleandra97@mail.ru

Гнитюк Алексей Андреевич, студент лечебного факультета ФГБОУ ВО Тихоокеанский ГМУ Минздрава России, г. Владивосток. E-mail: gnituk97@mail.ru

Почтовый адрес ФГБОУ ВО Амурская ГМА Минздрава России: 675000, Амурская область, г. Благовещенск, ул. Горького, 95. E-mail: AmurSMA@AmurSMA.su, science.dep@ AmurSMA.su

Потовый адрес ФГБОУ ВО Тихоокеанский ГМУ Минздрава России: 690002 г. Владивосток, ул. Острякова, 2.
УдК 576.31+(576.6:576.33)+576.017.35

И.Ю. Саяпина, ${ }^{1}$ С.А. Грищенко, ${ }^{2}$ A.A. 3 убов ${ }^{1}$

ФГБОУ ВО Амурская ГМА

Минздрава России ${ }^{1}$

г. Благовещенск

ГБУЗ АО «Амурская областная

психиатрическая больница» ${ }^{2}$

г. Благовещенск

\section{К ВОПРОСУ ПЛАСТИЧНОСТИ БАЗАЛЬНЫХ КЛЕТОК ЭПИТЕЛИЯ ЭПИДИДИМИСА}

Эпидидимис является важным органом мужского репродуктивного тракта, отвечающим за созревание, накопление, защиту и хранение сперматозоидов. Это место, где функционально некомпетентные половые клетки, вырабатываемые в яичках, окончательно созревают и накапливаются. В результате пассажа через проток эпидидимиса, который у представителей большинства видов занимает 1-2 недели, сперматозоиды претерпевают множество изменений, приобретая подвижность и способность к фертилизации $[5,7,33$, $35,36]$. Большинство из вышеперечисленных функций обеспечивает псевдомногослойный эпителий, выстилающий изнутри проток эпидидимиса, в состав которого входят главные, базальные, прозрачные, узкие и апикальные клетки $[5,7,33,35,36,41]$.

Важную роль в физиологии эпидидимиса имеет гемато-эпидидимальный барьер, поддержание структурной целостности которого обеспечивает мужскую фертильность [12, 15, 16, 19]. Повреждение структурных компонентов гемато-эпидидимального барьера приводит к развитию инфертильных состояний и формированию спермальных гранулем [1, 15, $19,32]$. Повреждения эпителия эпидидимиса могут быть вызваны повышением давления семенной жидкости (обтурационные повреждения), а также в результате действия внешних факторов, таких, как бактериальная инфекция, воспаление, химические агенты и лекарственные препараты $[1,12,15,19$, $27,30,37]$. Клеточное обновление является важнейшим свойством всех эпителиев и в первую очередь это касается эпителиальных клеток, формирующих плотные контакты, обеспечивающие барьерные свойства ряда эпителиев. Следовательно, поддержание динамического равновесия между апоптозом, клеточным обновлением и дифференцировкой, требует присутствия В эпидидимальном эпителии клетокпредшественников и/или стволовых клеток, способных обеспечить быстрый ответ при нарушении целостности эпителия. Эпителий эпидидимиса представляет собой довольно устойчивую ткань, демонстрирующую незначительные морфологические изменения при выраженных патологических 
воздействиях [10, 24, 31, 34]. Тем не менее, есть исследования, указывающие на усиление апоптоза в эпителии эпидидимиса при определенных состояниях [17, 24, 42]. При этом авторы указывают на сохранение целостности эпителия, что предполагает хорошо выраженную способность эпителия эпидидимиса к быстрой регенерации. Таким образом, присутствие в эпидидимисе клетокпредшественников и/или стволовых клеток, способных обеспечить быструю регенерацию эпителия, на сегодняшний день остается источником противоречий.

Источником обновления большинства псевдомногослойных эпителиев

B постнатальном онтогенезе являются базальные клетки. За счет пролиферации и дифференцировки базальных клеток обновляется псевдомногослойный эпителий воздухоносных путей, молочной железы и простаты. В эпителии простаты базальные клетки дают начало главным и нейроэндокринным клеткам, в эпителии трахеи они дифференцируются в специализированные реснитчатые клетки и секреторные клетки. Базальные клетки эпидидимиса (БКЭ) в препубертатном периоде онтогенеза развиваются из недифференцированных столбчатых клеток, которые так же дают начало главным и прозрачным клеткам эпителия [6, 7, 33, 35, 36, 41]. Многочисленные исследования показали, что БКЭ не являются предшественниками главных или прозрачных клеток и представляют собой популяцию высокоспециализированных клеток эпидидимиса [6, 33, 41]. Именно поэтому еще в 1975 году исследователь Дэвид Гамильтон (David W. Hamilton) в обзоре, посвященном структуре и функциям эпидидимиса, назвал БКэ загадкой [21]. В связи с этим на страницах данного обзора литературы будут рассмотрены БКЭ, проявляющие выраженную морфологическую пластичность, которые в настоящее время рассматриваются в качестве кандидатов на роль стволовых клеток эпидидимиса $[5,28,33,41]$. Иными словами, мы попытаемся рассмотреть современное состояние проблемы и ответить на вопрос, являются ли БКЭ загадкой и в настоящее время.

\section{Эпителий эпидидимиса}

Псевдомногослойный эпидидимиса состоит из нескольких различных типов клеток (рис. 1). В эпителии половозрелых особей доминируют главные клетки, выстилающие просвет протока, их доля составляет приблизительно 65-80\% от общего количества эпителиальных клеток [5, $7,33,35,36,39]$. Главные клетки участвуют в секреции белков и экзосом (эпидидимосом) в просвет протока эпидидимиса, где многие из них связываются с созревающими сперматозоидами [5, 7, 33, 35, 36]. БКЭ, которые располагаются на базальной мембране, как и базальныеклеткидругихпсевдомногослойных эпителиев, представляют второй по численности тип эпителиальных клеток, на долю которых приходится около 20\% [5, 7, 33, 35, 36, 39]. БКэ имеют тонкие и длинные латеральные отростки, которые простираются вдоль базальной мембраны, а также апикальный отросток, который ориентирован вертикально, по направлению к просвету [35]. Узкие, прозрачные и апикальные клетки участвуют в секреции протонов $\mathrm{H}^{+}$, что обеспечивает подкисление просветной среды, необходимое для инактивации сперматозоидов на время пассажа по протоку эпидидимиса $[5,7$, $33,35,36]$. Главные и прозрачные клетки также отвечают за клиренс белков из просветного содержимого путем эндоцитоза $[5,7,33$, 35, 36, 39]. Эпителий эпидидимиса содержит иммунные клетки, в том числе клетки с узким ободком цитоплазмы (halo cells), которые являются резидентными моноцитами/макрофагами, и дендритными клетками [13, 14, 33].

\section{Базальные клетки эпителия эпидидимиса}

$\begin{array}{ccc}\text { Термин «базальные } & \text { клетки» } \\ \text { для описания } & \text { клеток, }\end{array}$
используется для описания клеток, локализующихся в базальном компартменте псевдомногослойных эпителиев, и контактирующих с базальной мембраной. БКЭ - это второй по численности тип клеток в эпителии эпидидимиса, они составляют 15-20\% от общей клеточной популяции $[5,7,33,35,36$, 39]. На сегодняшний день БКЭ описаны у всех представителей млекопитающих, включая человека. Обзор литературных источников

Резюме Базальные клетки эпителия эпидидимиса проявляют морфологическую и функциональную пластичность, что делает их объектом многочисленных научных исследований и предметом дискуссий. Известно, что базальные клетки эпидидимиса представляют собой высокоспециализированную клеточную популяцию и не являются предшественниками других клеток эпидидимального эпителия. В то же время способность эпителия эпидидимиса поддерживать целостность после повреждения предполагает наличие регенеративного механизма, который может быть обеспечен присутствием предшественников и / или стволовых клеток в эпителии. В обзоре кратко изложены современные взгляды на структуру и функции базальных клеток, рассмотрена их роль в поддержании целостности и регенерации эпителия эпидидимиса. Представлены новые данные о базальных клетках эпидидимиса как потенциальных взрослых стволовых клетках, полученные с использованием 3D культуры клеток.

Ключевые слова: эпидидимис, эпителий, базальные клетки, взрослые стволовые клетки, регенерация 


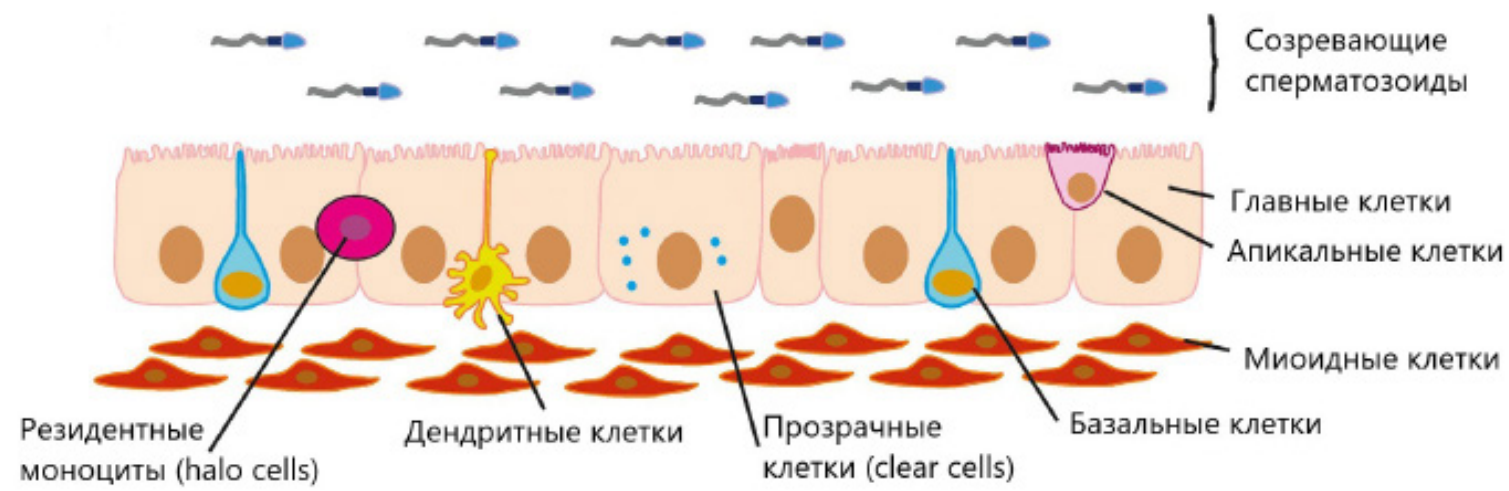

Рисунок 1. Схематичное изображение эпителия эпидидимиса, демонстрирующее различные типы клеток, представленных в эпителии половозрелых особей (L. Pinel et al., 2019).

показал, что в последние годы уделяется большое внимание морфологическим характеристикам БКЭ $[5,7,24,28,33,35,36$, $38,39,46,47]$.

БКЭ имеют тело в форме полусферы, содержащее ядро округлой или удлиненной формы, широким основанием клетки прикрепляются к базальной мембране. От тела клетки отходят тонкие боковые выросты, простирающиеся вдоль базальной мембраны, которые контактируют с такими же выростами соседних БКЭ, формируя в базальном компартменте эпителия сеть наподобие корзинки [5, 7, 33, 35, 36, 39], исходя из этого была предложена структурная функция БКЭ [5]. Апикальный отросток БКЭ всегда направлен к поверхности эпителиального пласта, и относительно недавно (вплоть до 2008 года) считалось, что БКЭ, как и базальные клетки других псевдомногослойных эпителиев, не достигают поверхности эпителия (рис. 2).

Однако представления о морфологии БКЭ в последние годы сильно изменились, когда Shum et. al. [39] иммуногистохимически с использованием двойной метки впервые было установлено, что апикальные отростки многих БКэ поднимаются по направлению к просвету эпидидимиса (рис. 3), где пересекают zonulae adherentes и плотных контактов между главными клетками, участвуя тем самым, в формировании гемато-эпидидимального барьера, и контактируя с просветным содержимым [33, 39, 41].

Ультраструктурная морфология БКЭ изучена и достаточно подробно описана в работах [5, 35, 39, 46]. Цитоплазма БКэ характеризуется слабым развитием органелл, что более типично для малодифференцированных клеток (рис. 2). В ней присутствуют микропиноцитозные везикулы, диспергированные профили эндоплазматической сети, единичные митохондрии и маленький комплекс Гольджи без определенной локализации. Также в цитоплазме БКЭ описаны пучки микрофиламентов $[5,41,46]$, что подтверждают экспрессия и коэкспрессия различных видов цитокератинов в цитоплазме этих клеток, в том числе цитокератина-5 (KRT5), характерного для базальных клеток псевдомногослойных эпителиев (рис. 3).

Контуры плазмалеммы по боковым поверхностям БКэ характеризуются наличием выростов и впячиваний, которые в совокупности формируют интердигитации для соединения с соседними клетками эпителия. Плазмалемма в базальной

\title{
TO THE ISSUE OF PLASTICITY OF BASAL CELLS OF THE EPIDIDYMAL EPITHELIUM
}

\author{
I.Yu. Sayapina, ${ }^{1}$ S.A. Grishchenko, ${ }^{2}$ A.A. Zubov ${ }^{1}$
}

FSBEI HE the Amur state medical Academy of the Ministry of Public Health of Russia, ${ }^{1}$ Blagoveshchensk; GBUZ JSC «Amur Regional Psychiatric Hospital»², Blagoveshchensk

Abstract The epididymal basal epithelial cells demonstrate morphological and functional plasticity, which makes them the subject of numerous scientific studies and the subject of discussion. It is known that epididymal basal cells represent a highly specialized cell population and they are not precursors of other epididymal epithelial cells. At the same time the ability of an epididymal epithelium to maintain integrity after damage suggests a regenerative mechanism that can be provided by the presence of progenitor and / or stem cells in the epithelium. The review summarizes modern views on the structure and functions of basal cells, considers their role in maintaining the integrity and regeneration of the epididyma epithelium. New data on epididymal basal cells as potential adult stem cells obtained using 3D cell culture are presented.

Key words: epididymis, epithelium, basal cells, adult stem cells, regeneration. 


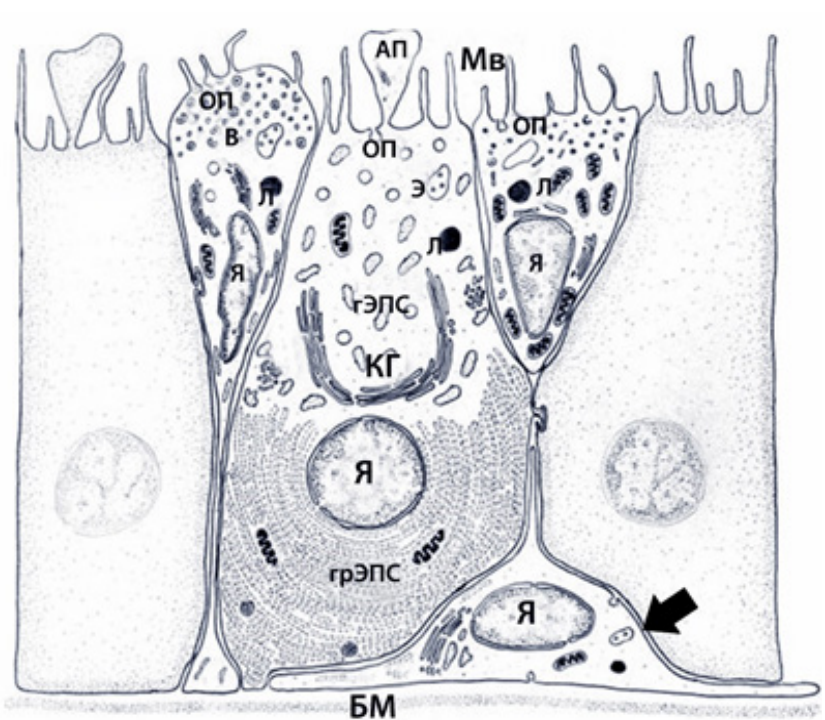

Рисунок 2. Схематичное изображение эпителия начального сегмента эпидидимиса, демонстрирующее ультраструктурную организацию клеток различных типов. В базальном компартменте эпителия изображена БКЭ (стрелка), в центре изображена главная клетка, слева - узкая клетка, справа - апикальная клетка (B. Robaire et al., 2006).

части БКэ ровная, там обнаруживаются полудесмосомы, посредством которых клетки прикрепляются к базальной мембране эпителия. Иммуногистохимически в клеточной мембране БКэ была установлена локализация коннексина-43 (Сх43), участвующего в формировании щелевых контактов БКЭ с главными и прозрачными клетками, ряда адгезионных белков, а также белка плотных контактов клаудина-1 [7, 12, 16, 33, 39, 41].

\section{Мнения большинства}

авторов относительно функций БКЭ сходятся в одном: функции клеток чрезвычайно многообразны, но многие из них до конца еще не изучены $[5,7,12,28,33,35]$. Наличие в цитоплазме БКэ окаймленных пузырьков предполагает их участие в рецепторно-опосредованном эндоцитозе веществ, поступающих из крови, и из цитоплазмы главных клеток [35]. В ряде исследований установлено наличие в БКЭ ферментов, участвующих в метаболизме активных форм кислорода (Cu-Zn-зависимой супероксиддисмутазы, некоторых изоформ глутатион-S-трансферазы, металлотеинеинов) $[3,11,25]$.

Экспрессия БКЭ антигенов макрофагов в ответ на появление в просвете эпидидимиса спермальных аутоантигенов, обнаруженная Seiler P. et al. [38], стала предметом дискуссии об иммунной функции этих клеток. Предполагалось, что БКЭ выполняют роль резидентных макрофагов, защищающих сперматозоиды от иммунной системы [47]. Однако недавнее открытие дендритных клеток в эпидидимальном эпителии позволяет предположить, что иммунные функции, изначально приписываемые БКЭ, могут быть присущи дендритным клеткам, которые так же располагаются в непосредственной близости от базальной мембраны эпителия [13, 14].

Открытие длинных апикальных отростков у БКЭ, пересекающих гемато-эпидидимальный барьер, и достигающих просвета эпидидимиса [39], навело ученых на ряд новых и интересных функций клеток. БКэ была предложена функция люминальных сенсоров, которые контролируют просветное содержимое эпидидимиса, и через полученную информацию регулируют функции главных клеток [40]. Это подтверждается высоким уровнем экспрессии БКэ циклооксигеназы-1 и секрецией простагландинов E2 и D, которые регулируют функции главных клеток [13, 20, 45]. Другая функция БКЭ, связанная с открытием W. Shum et. al. [39] - это участие клеток в поддержании целостности гемато-эпидидимального барьера, имеющего решающее значение для мужской фертильности [5, 12, 41].

Таким образом, к настоящему времени функции БКЭ окончательно не установлены, разработка новых методов и подходов к изучению БКЭ сопровождается уточнением и пересмотром ряда функций этих клеток $[12,28$, $33,39]$, что не исключает вероятность появления в недалеком будущем новых и интересных сведений о физиологии БКЭ.
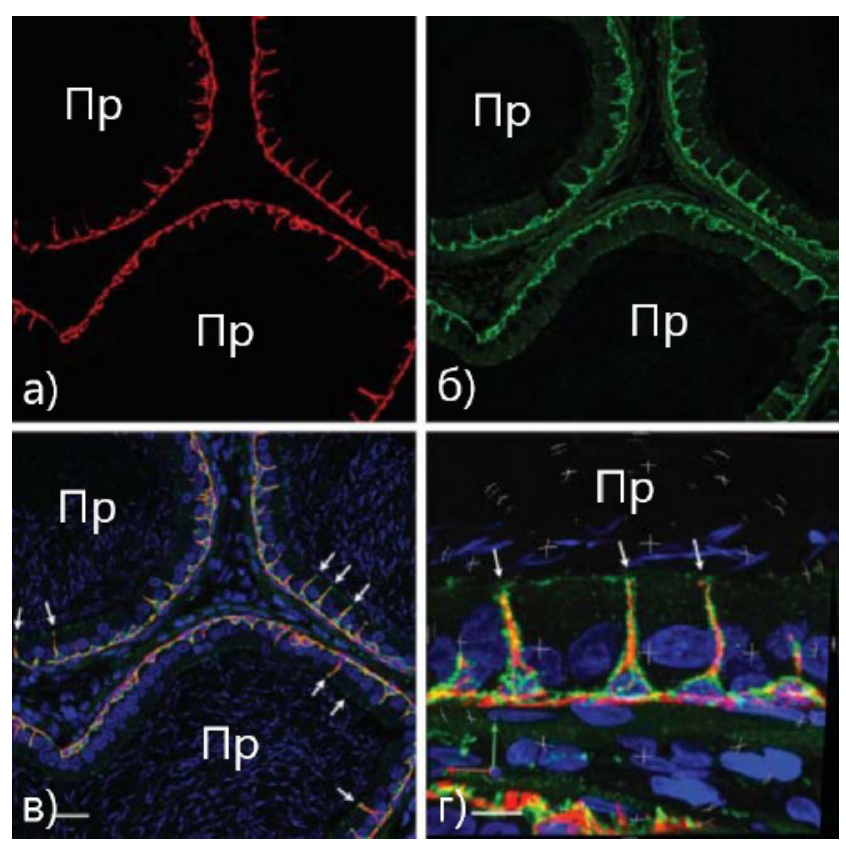

Рисунок 3. Проекционные изображения БКЭ, полученные путем наложения 13 конфокальных изображений с интервалом 1 мкм. а) красный цвет - БКЭ, меченные для КRT5; б) зеленый цвет - БКЭ, меченные для клаудина-1 (белок клеточной адгезии, маркер базальных клеток); в) БКЭ с двойной меткой (КRT5 и клаудин-1); r) 3-D изображение БКЭ с двойной меткой (KRT5 и клаудин-1) на большом увеличении. Стрелками показаны апикальные отростки БКЭ, достигающие просвета эпидидимиса (W. Shum et al., 2013). 
Пролиферация клеток и регенерация эпителия эпидидимиса

Пролиферация и регенерация клеток в эпидидимальном эпителии была предметом нескольких исследований [9, 22, 31, 34, 43]. В ранних исследованиях по оценке пролиферации клеток в эпидидимисе с использованием меченного тритием тимидина (3H-TdR) был сделан вывод о том, что в эпидидимисе взрослых крыс и мышей пролиферация клеток происходит с относительно низкой скоростью, обновляются как главные, так и БКЭ $[9,31]$. R. Ramirez et al. [34], исследовавшие пролиферацию клеток в эпидидимисе с помощью мечения бромдезоксиуридином (BrdU), сообщили, что БКЭ начинают пролиферировать у пубертатных крыс и что их пролиферация с возрастом снижается. Этими же авторами была отмечена более низкая скорость пролиферации БКЭ по сравнению с главными клетками. В другом исследовании эпидидимиса взрослых крыс при помощи BrdU было показано, что большая часть окрашивания обнаруживалась в главных клетках, а также в БКЭ, узких и прозрачных клетках в зависимости от сегмента [22]. Эти исследования показали, что, как БКЭ, так и главные клетки эпидидимиса, подвержены пролиферации, но митотический индекс клеток крайне низкий. В то же время результаты приведенных исследований не исключают возможности существования в эпидидимисе покоящихся стволовых клеток.

В экспериментальных исследованиях по лигированию семявыносящего протока (ЛСП) у мышей было установлено, что в первые сутки после перевязки наблюдаются выраженная дегенерация главных клеток и исчезновение фигур митоза, но через 2-3 дня за этим следовало увеличение митотической активности эпителия $[2,44]$. X. Fan and B. Robaire [17] сообщили, что орхидэктомия у крыс индуцировала волну апоптоза на всем протяжении эпидидимиса, однако за усилением апоптоза следовала относительно быстрая регенерация клеток, что поддерживало целостность эпителия. Интересно, что в исследовании М. Hamzeh [22] усиление регенерации после лсп было отмечено только после восстановления уровня тестостерона. Эти наблюдения показывают, что клеточная пролиферация и апоптоз в эпидидимисе регулируются сочетанием люмикринных факторов и андрогенов. Более поздние исследования показали, что в начальном сегменте и головке эпидидимиса сохраняется целостность эпителия, несмотря на 6-кратное увеличение апоптоза через 48 часов после операции ЛСп [24, 42]. Поддержание плотных контактов и структуры эпителия в целом при таких высоких показателях апоптоза и при отсутствии резерва столбчатых клеток, предполагают наличие регенеративного механизма, который может быть обеспечен присутствием клеток-предшественников и / или стволовых клеток в эпителии [42]. В. Kim et al. [24] сообщили, что оба типа клеток

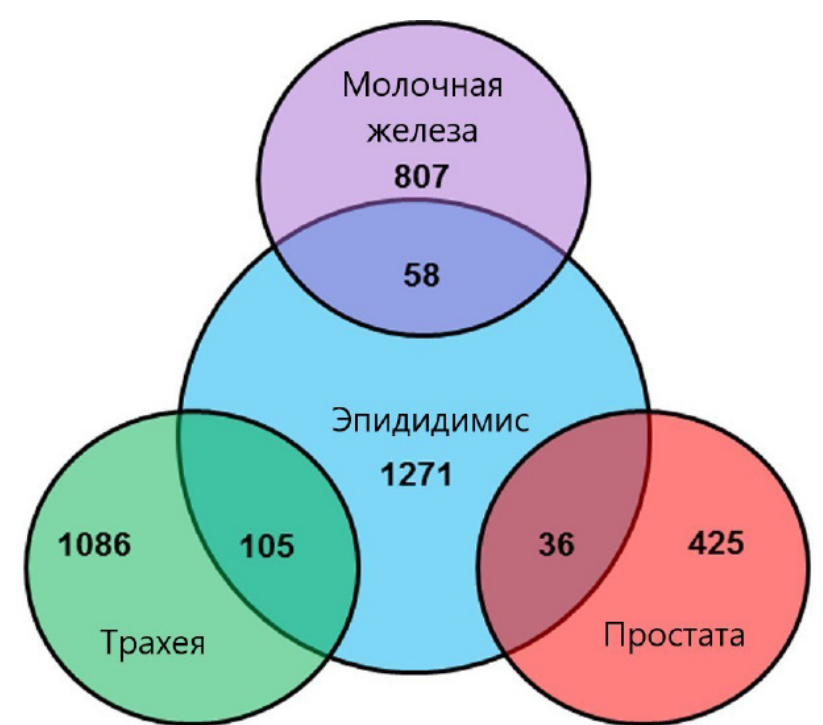

Рисунок 4. Экспрессия генов в базальных клетках. Представлены общие гены между БКэ и базальными клетками других псевдомногослойных эпителиев, таких, как эпителий трахеи, простаты и молочной железы. Представленные данные были получены путем сравнения профилей экспрессии генов, сделанных в разных исследованияx (L. Pinel et al., 2019).

(главные и базальные) дегенерировали путем апоптоза через 2 дня после операции, однако выжившие БКЭ ответили ускоренной пролиферацией, которая достигла пика через 2 дня, а морфология эпителия вернулась к норме через 5 дней после лигации. В то же время у крыс, получавших антиандроген флутамид, через 2 дня после лигирования пролиферативная активность БКЭ снижалась, что подтверждает мнение о влиянии андрогенов на процессы пролиферации [24]. Следовательно, такие процессы, как апоптоз, пролиферация и дифференцировка клеток эпидидимиса у животных могут протекать под влиянием андрогенов достаточно быстро. Однако для того, чтобы сделать окончательный вывод о том, что в основе поддержания целостности эпителия эпидидимиса лежит образование новой генерации главных клеток из БКЭ, необходимы новые эксперименты по отслеживанию их клеточных линий [33].

\section{БКЭ как потенциальные взрослые стволовые клетки}

Исследования показали наличие различных паттернов и уровней мРНК коннексинов в эпидидимисе крыс на протяжении всего периода постнатального онтогенеза. Экспериментально установлено, что экспрессия Сх26 и Сх43 характерна для самых ранних стадий постнатального развития, до начала дифференцировки эпителия эпидидимиса $[16,43]$. Недавно M. Gregory and D. Cyr (2018) сообщили, что в эпидидимисе молодых крыс Cх43 локализуется в апикальных частях недифференцированных клеток по их боковым поверхностям. В ходе дифференцировки в базальном компартменте эпителия эпидидимиса появля- 


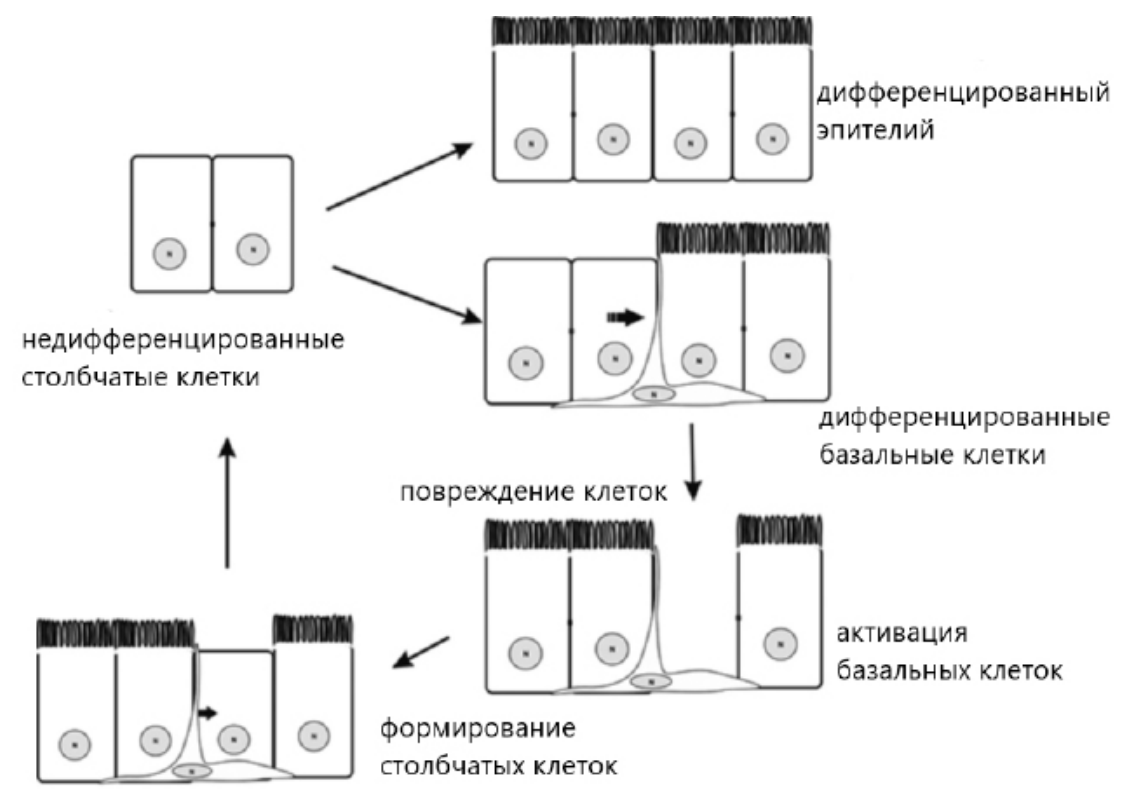

Рисунок. 5. Модель регенерации и дифференцировки клеток эпителия эпидидимиса. Повреждение эпителия эпидидимиса стимулирует БКЭ к пролиферации и дифференцировке в столбчатые клетки, которые впоследствии будут дифференцироваться в другие эпителиальные клетки, включая главные и прозрачные клетки (Mandon et al., 2015).

ются ТР63-позитивные (ТР63 - транскрипционный фактор) БКЭ, иммунолокализация Сх43 перемещается в базальную часть эпителия, где Сх43 экспрессируется уже БКЭ [23]. Экспрессия ТР63 и Сх43 в недифференцированных столбчатых клетках придатка представляет особый интерес, так как позволяет предположить, что на раннем этапе постнатального развития ТР63-позитивные БКЭ сохраняют недифференцированную морфологию, сходную с таковой у столбчатых недифференцированных клеток. Есть вероятность, что в эпителии эпидидимиса существует резидентная популяция клеток, сохраняющих недифференцированный фенотип, которая может иметь сходство с популяцией клеток, экспрессирующих ТР63 на ранних стадиях постнатального развития [33].

Сх43, экспрессируемый БКЭ, участвует в создании специализированного микроокружения для различных типов стволовых клеток [18]. Было установлено, что Сх43 регулирует обновление стволовых клеток в головном мозге, коже, костном мозге, молочной железе и простате [18]. Хотя роль Сх43 в обновлении БКЭ не установлена, известно, что в тканях, где базальные клетки действуют как стволовые клетки, Cx43 играет ключевую роль в регуляции обновления стволовых клеток.

Самые ранние исследования процессов дифференцировки эпителия эпидидимиса в постнатальном онтогенезе у крыс показали, что недифференцированные столбчатые клетки эпителия дифференцируются в главные клетки, прозрачные и БКЭ [43]. Намного позже A. Murashima et al. [29] сообщили, что БКЭ не нужны для дифференцировки главных, прозрачных и узких клеток в эпидидимисе мышей, и относительно недавно W. Shum et al. [41] также пришли к выводу, что БКЭ не являются предшественниками главных и прозрачных клеток.

Заслуживает внимания повышенный уровень экспрессии БКЭ антиапоптотического белка BCL-2, обнаруженный в исследовании [34]. Авторы сообщили, что приблизительно 61\% иммуноокрашивания на BCL-2 в эпителии эпидидимиса обнаруживается в БКЭ как у взрослых, так и у препубертатных животных. BCL-2 представляет собой онкопротеин, который придает клеткам апоптотическую устойчивость, он был обнаружен во многих популяциях стволовых клеток. Эта особенность апоптотической резистентности может объяснить, почему БКЭ могут выживать после Лсп [24].

Существенным шагом вперед стала разработанная M. Mandon et al. [28] стратегия получения высокообогащенной популяции БКЭ из эпидидимиса крыс, содержащей более $90 \%$ базальных клеток. Транскриптомный анализ БКЭ in vitro показал, что они тотально экспрессировали TP63, а также множественные коннексины (Сх43, 32, 30.3 и 31.1), маркеры воспаления, гены, участвующие в детоксикации, и маркеры взрослых стволовых клеток [28]. Некоторые из генов, экспрессируемых БКЭ обогащенной фракции, также экспрессируются в базальных клетках других тканей включая простату, молочную железу и трахею [33]. Однако профили экспрессии генов этих тканей показали, что многие транскрипты базальных клеток являются тканеспецифичными, предполагая некоторые различия между базальными клетками в составе разных псевдомногослойных эпителиев (рис. 4). Интересно, что экспрессия TP63 характерна для базальных клеток всех псевдомногослойных эпителиев. Кроме того, анализ in silico предполагает, что в эпителии эпидидимиса ТР63-зависимые гены 
регулируют процессы клеточной адгезии, клеточный цикл, дифференцировку, развитие и пролиферацию [28, 33].

Основной характеристикой мультипотентных стволовых клеток является их способность размножаться и дифференцироваться в клетки органа, из которого они происходят. Отчасти поэтому стволовые клетки способны размножаться при культивировании в Матригеле, образуя сферу клеток (2D культура). Образование сфер из диспергированных клеток эпидидимиса человека в условиях 2D культуры наблюдали D. Kristensen et al. [26]. M. Mandon et al. [28] сообщили о появлении ацинусов в культивируемых БКЭ крыс, клетки которых экспрессировали маркер базальных клеток KRT5 после чего утрачивали способность к экспрессии KRT5 и начинали экспрессировать KRT8, который характерен для главных клеток эпителия эпидидимиса. Также во многих ацинусах появлялись клетки, экспрессировавшие Cx26, что характерно для недифференцированных столбчатых клеток эпителия эпидидимиса $[16,43]$. Эти наблюдения привели авторов к предположению, что внутри ацинусов БКэ дифференцируются сначала в столбчатые клетки, а затем в главные клетки, на основе чего была разработана модель регенерации и дифференцировки эпителия эпидидимиса (рис. 5)

Чтобы окончательно прояснить вопрос, способны ли БКЭ вернуться к столбчатым клеткам в ответ на повреждение ткани, а также для изучения факторов, регулирующих эту дифференциацию, был разработан более сложный протокол для трехмерной (3D) клеточной культуры с возможностью получения органоидов [33]. По мнению авторов, новый подход с образованием эпидидимальных органоидов должен был или подтвердить гипотезу о наличии стволовых клеток в эпидидимисе, или сделать ее несостоятельной. Ферментативно диспергированные единичные клетки эпидидимиса половозрелых крыс культивировали в Матригеле для создания 3D культуры этих клеток. После 2-го дня культивирования клетки образовывали маленькие сферические структуры, впоследствии сферы становились более регулярными, количество и размеры клеток, а также диаметр сфер увеличивался после 3-го дня культивирования, сложность этих структур со временем так же увеличивалась, что делало их похожими на органоиды, которые были получены из клеток других тканей $[4,8,10,26]$. Таким образом, результаты, полученные в исследовании L. Pinel et al. [33], подтвердили гипотезу о существовании мультипотентных взрослых стволовых клеток в эпидидимальном эпителии. Так же авторы считают, что дальнейшее развитие технологии выращивания эпидидимальных органоидов в 3D культуре создаст мощный новый инструмент для изучения вопросов клеточной пролиферации и дифференцировки в этом органе.

\section{Выводы}

1. В постнатальном онтогенезе БКэ представляют собой популяцию высокоспециализированных клеток эпидидимиса, выполняющих множественные функции, и не являются предшественниками главных или прозрачных клеток эпидидимального эпителия.

2. Способность эпителия эпидидимиса поддерживать целостность после повреждения предполагает наличие регенеративного механизма, который может быть обеспечен присутствием клеток-предшественников и / или стволовых клеток в эпителии.

3. БКЭ проявляют общие свойства со взрослыми стволовыми клетками, что доказано экспрессией БКэ маркеров взрослых стволовых клеток, способностью БКЭ образовывать сферические структуры в 2D клеточной культуре, а также формированием органоидов с использованием протоколов 3D клеточных культур.

4. Использование эпидидимальных органоидов предоставляет уникальный инструмент для изучения эпидидимальных стволовых клеток и механизмов их регуляции в норме и при патологических состояниях.

5. Дальнейшее изучение и понимание процессов регенерации эпителия эпидидимиса поможет предложить новые клинические подходы по преодолению повреждения тканей эпидидимиса при инфекциях, обструкции или химических повреждениях.

\section{Литература}

1. Белый Л.Е., Коньшин И.И. Гематоэпидидимальный барьер и его повреждение при инфекционном воспалении в придатке яичка // Современные проблемы науки и образования. 2017. № 2. URL: http://www. science-education.ru/ru/article/view? $\mathrm{id}=26189$ (30.07.2019 г.)

2. Abe K., Takano H. Early degeneration of the epithelial cells in the initial segment of the epididymal duct in mice after efferent duct cutting // Arch. Histol. Cytol. 1989. Vol. 52. P. 299 - 310.

3. Aghaie S., Nikzad H. et al. Protective effect of combined pumpkin seed and ginger extracts on sperm characteristics, biochemical parameters and epididymal histology in adult male rats treated with cyclophosphamide // Anat. Sci. Int. 2016. Vol. 91. P. $382-390$.

4. Alves-Lopes J.P., Soder O. et al. Testicular organoid generation by a novel in vitro three-layer gradient system // Biomaterials. 2017. Vol. 130. P. $76-89$.

5. Arrighi S. Are the basal cells of the mammalian epididymis still an enigma // Reproduction, Fertility and Development. 2014. Vol. 26. P. 1061 -1071 . 
6. Arroteia K.F., Garcia P.V. et al. The Epididymis: Embryology, Structure, Function and Its Role in Fertilization and Infertility // 2012. URL: http://www.intechopen.com/books /embryology-updates-and-highlightson-classic-topics/ (30.07.2019 г.)

7. Breton S., Chun R.Ye. et al. Regulation of epithelial function, differentiation, and remodeling in the epididymis // Asian Journal of Andrology. 2016. Vol. 18. P. 3 - 9.

8. Boretto M., Cox B. et al. Development of organoids from mouse and human endometrium showing endometrial epithelium physiology and long-term expandability // Development. 2017. Vol. 144. P. $1775-1786$.

9. Clermont Y., Flannery J. Mitotic activity in the epithelium of the epididymis in young and old adult rats // Biol. Reprod. 1970. Vol. 3. P. 283 292.

10. Clevers H. Modeling development and disease with organoids // Cell. 2016. Vol. 165. P. $1586-1597$.

11. Cyr D.G., Dufresne J., Pillet S. et al. Expression and regulation of metallothioneins in the rat epididymis // J. Androl. 2001. Vol. 22. P. 124-135.

12. Cyr D.G., Dufresne J., Gregory M. Cellular junctions in the epididymis, a critical parameter for understanding male reproductive toxicology // Reprod. Toxicol. 2018. Vol. 81. P. $207-219$.

13. Da Silva N., Smith T.B. Exploring the role of mononuclear phagocytes in the epididymis // Asian Journal of Andrology. 2015. Vol. 17. P. 591 $-596$.

14. Da Silva N., Barton C.R. et al. Macrophages and Dendritic Cells in the Post-testicular // Environment Cell Tissue Res. 2016. Vol. 363. № 1. P. $97-104$.

15. Dube E., Hermo L., Chan P.T. et al. Alterations in the human blood-epididymis barrier in obstructive azoospermia and the development of novel epididymal cell lines from infertile men // Biol. Reprod. 2010. Vol. 83. P. $584-596$.

16. Dufresne J., Finnson K.W., Gregory M. et al. Expression of multiple connexins in the rat epididymis indicates a complex regulation of gap junctional communication // Am. J. Physiol. Cell. Physiol. 2003. Vol. 284. P. $33-43$.

17. Fan X., Robaire B. Orchidectomy induces a wave of apoptotic cell death in the epididymis // Endocrinology. 1998. Vol. 139. P. 2128- 2136.

18. Genet N., Bhatt N. et al. Multifaceted roles of connexin 43 in stem cell niches // Curr. Stem Cell Rep. 2018. Vol. 4. P. $1-12$.

19. Gregory M., Cyr D.G. The blood-epididymis barrier and inflammation // Spermatogenesis. 2014. Vol. 4. URL: https://www.ncbi.nlm.nih.gov/ pmc/articles/PMC4581054/ (30.07.2019 г.)
20. Gregory M., Cyr D.G. Effects of prostaglandin E2 on gap junction protein alpha 1 (GJA1) in the rat epididymis // Biol. Reprod. 2018. Vol. 100. P. $123-132$.

21. Hamilton D.W. Structure and function of the epithelium lining the ductuli efferentes, ductus epididymis and ductus deferens in the rat // Handbook of Physiology, Section 7, Endocrinology. 1975. Vol. V. Male Reproductive System., Hamilton D.W., Creep R.O. P. 259 - 301. Washington, DC.: American Physiological Society.

22. Hamzeh M., Robaire B. Effect of testosterone on epithelial cell proliferation in the regressed rat epididymis // J. Androl. 2009. Vol. 30. P. 200 $-212$.

23. Hayashi T., Yoshinaga A., Ohno R. et al. Expression of the p63 and Notch signaling systems in rat testes during postnatal development: comparison with their expression levels in the epididymis and vas deferens // J. Androl. 2004. Vol. 25. P. $692-698$.

24. Kim B., Roy J., Shum W.W. et al. Role of testicular luminal factors on Basal cell elongation and proliferation in the mouse epididymis // Biol. Reprod. 2015. Vol. 92. P. 9. URL: https://www. ncbi.nlm.nih.gov/pmc/articles/PMC4434934/ (30.07.2019 г.)

25. Kolasa-Wolosiuk A., Tarnowski M. et al. Antioxidant enzyme expression of mRNA and protein in the epididymis of finasteride-treated male rat offspring during postnatal development // Arch. Med. Sci. 2019. Vol. 15. № 3. P. $797-810$.

26. Kristensen D.M., Nielsen J.E. et al. OCT4 and downstream factors are expressed in human somatic urogenital epithelia and in culture of epididymal spheres // Mol. Hum. Reprod. 2010. Vol. 16. P. $835-845$.

27. Leite G., Adan A. et al. Lower sperm quality and testicular and epididymal structural impairment in adult rats exposed to rosuvastatin during prepuberty // J. Appl. Toxicol. 2018. Vol. 38. P. $914-929$.

28. Mandon M., Hermo L., Cyr D.G. Isolated rat epididymal basal cells share common properties with adult stem cells // Biol. Reprod. 2015. Vol. 93. P. 115. URL: https://www.ncbi.nlm.nih.gov/ pmc/articles/PMC4712003/(30.07.2019 г.)

29. Murashima A., Miyagawa S. et al. Essential roles of androgen signaling in Wolffian duct stabilization and epididymal cell differentiation // Endocrinology. 2011. Vol. 152. P. 1640 - 1651.

30. Nirmal N.K., Awasthi K.K. et al. Effects of Nano-Graphene Oxide on Testis, Epididymis and Fertility of Wistar Rats Basic \& Clinical Pharmacology \& Toxicology. // 2017. Vol. 121. P. $202-210$.

31. Pabst R., Schick P. Proliferation of epithelial cells of vas deferens and epididymis in young adult rabbits // Arch. Androl. 1979. Vol. 2. P. 183 $-186$. 
32. Park D., Lee B. et al. Higher incidence of sperm granuloma in the epididymis of C57BL/6N mice // Lab. Anim. Res. 2018. Vol. 34. № 1. P. 20 - 29.

33. Pinel L., Mandon M., Cyr D.G. Tissue regeneration and the epididymal stem cell // Andrology. 2019. P. 1 - 13.

34. Ramirez R., Martin R. et al. Changes in the number, proliferation rates, and $\mathrm{bcl}-2$ protein immunoexpression of epithelial and periductal cells from rat epididymis during postnatal development // J. Androl. 1999. Vol. 20. P. $702-712$.

35. Robaire B., Hinton B.T., Orgebin-Crist M-C. The Epididymis //'Raven Press, New York.: The Physiology of the Reproduction. 2006. P. $1072-1148$.

36. Robaire B., Hinton B.T. The Epididymis // Elsevier. Amsterdam.: Knobil and Neill's Physiology of Reproduction. 2015. P. $691-771$.

37. Santi F., Beltrame F.L. et al. Reduced levels of stromal sex hormone-binding globulin and androgen receptor dysfunction in the sperm storage region of the rat epididymis // Reproduction. 2018. Vol. 152. P. $467-479$.

38. Seiler P., Cooper T.G., Nieschlag E. Sperm number and condition affect the number of basal cells and their expression of macrophage antigen in the murine epididymis // J. Androl. 2000. Vol. 23. P. $65-76$.

39. Shum W.W., Da Silva N. et al. Transepithelial projections from basal cells are luminal sensors in pseudostratified epithelia // Cell. 2008. Vol. 135. P. $1108-1117$.

40. Shum W.W., Da Silva N., Brown D. et al. Regulation of luminal acidification in the male reproductive tract via cell-cell crosstalk // J. Experiment Biol. 2009. Vol. 212. P. 1753 - 1761.

41. Shum W.W., Hill E. et al. Plasticity of basal cells during postnatal development in the rat epididymis // Reproduction. 2013. Vol. 146. P. 455- 469.

42. Smith T.B., Cortez-Retamozo V., et al. Mononuclear phagocytes rapidly clear apoptotic epithelial cells in the proximal epididymis // Andrology. 2014. Vol. 2. P. $755-762$.

43. Sun E.L., Flickinger C.J. Proliferative activity in the rat epididymis during postnatal development // Anat. Rec. 1982. Vol. 203. P. 273 - 284.

44. Turner T.T., Riley T.A. P53 independent, region-specific epithelial apoptosis is induced in the rat epididymis by deprivation of luminal factors // Mol. Reprod. Dev. 1999. Vol. 53. P. $188-197$.

45. Wong P.Y., Chan H.C. et al. Regulation of anion secretion by cyclo-oxygenase and prostanoids in cultured epididymal epithelia from the rat // J. Physiol. 1999. Vol. 514. № 3. P. $809-820$.

46. Yeung C.H., Cooper T.G. et al. Organization of tubules in the human caput epididymidis and the ultrastructure of their epithelia // Am. J. Anat. 1991. Vol. 191. P. $261-279$.

47. Yeung C.H., Nashan D. et al. Basal cells of the human epididymis-antigenic and ultrastructural similarities to tissue-fixed macrophages // Biol. Reprod. 1994. Vol. 50. P. $917-926$.

Статья поступила в редакцию 03.09.2019

\section{Координаты для связи}

Саяпина Ирина Юрьевна, д.б.н., профессор кафедры гистологии и биологии ФГБОУ ВО Амурская ГМА Минздрава России. E-mail: sayapina_agma@mail.ru

Грищенко Сергей Антонович, врач ГБУз АО «Амурская областная психиатрическая больница».E-mail: ziehf@yandex.ru.

Зубов Алексей Андреевич, ассистент кафедры гистологии и биологии ФГБОУ ВО Амурская ГМА Минздрава России.

Почтовый адрес ФГБОУ ВО Амурская ГМА Минздрава России: 675000, г. Благовещенск, ул. Горького, 95, кафедра гистологии и биологии.

Почтовый адрес ГБУЗ АО «Амурская областная психиатрическая больница»: 675000, г. Благовещенск, ул. Больничная, $32 / 2$. 